\title{
Experimental analysis of fire resistance of mortar coatings on structural masonry walls
}

Gustavo Prager (Main Author)

University of Vale do Rio dos Sinos/UNISINOS, Civil Engineering Department

93022-750, São Leopoldo (Brazil)

pragergustavo@gmail.com

https://orcid.org/0000-0001-9917-3144

\section{Rodrigo Périco}

University of Vale do Rio dos Sinos/UNISINOS, Civil Engineering Department 93022-750, São Leopoldo (Brazil)

pericorodrigo@gmail.com

https://orcid.org/0000-0002-5228-3108

\section{Giovana Poleto}

University of Vale do Rio dos Sinos/UNISINOS, Civil Engineering Department 93022-750, São Leopoldo (Brazil)

giovanapoleto@unisinos.br

https://orcid.org/0000-0003-3121-2156

\section{Fabrício Longhi Bolina}

University of Vale do Rio dos Sinos/UNISINOS, Civil Engineering Department 93022-750, São Leopoldo (Brazil)

fabriciolb@unisinos.br

https://orcid.org/0000-0002-0495-099X

\section{Bernardo Fonseca Tutikian (Corresponding Author)}

University of Vale do Rio dos Sinos/UNISINOS, Civil Engineering Department 93022-750, São Leopoldo (Brazil)

Universidad de la Costa, CUC, Department of Civil and Environmental

Calle 58 \# 55-66, Barranquilla, Atlántico (Colombia)

bftutikian@unisinos.br

https://orcid.org/0000-0003-1319-0547

Manuscript Code: 13834

Date of Acceptance/Reception: 25.11.2020/09.04.2020

DOI: 10.7764/RDLC.19.3.311

\begin{abstract}
The discussion on fire safety is necessary in Brazilian buildings. Current legislation requires construction with compartmentalized areas separated by walls with structural ceramic blocks capable of resisting fire for an amount of time pre-determined in norm NBR 14432 (ABNT, 2001 ). However, a lack of building standards requires experimental tests according to NBR 5628 (ABNT, 2001) to determine the necessary configuration to achieve fire resistance. For this purpose, this study analyzed the effect of fire on structural walls covered with a mortar coating. Experiments were conducted in real scale in a standardized vertical oven and the fire growth curve of ISO 834 (ISO, 1999). Three types of walls were tested, each with a different mortar coating: (a) lime; (b) $0.6 \mathrm{~kg} / \mathrm{m}^{3}$ polypropylene fiber and $1.2 \mathrm{~kg} / \mathrm{m}^{3}$ polypropylene fiber. The mortar coatings were $1.5 \mathrm{~cm}$ thick on the side facing the fire and $2.5 \mathrm{~cm}$ thick in the outside. The wall was composed of structural blocks measuring $14 \mathrm{~cm} \times 19 \mathrm{~cm} \times 29 \mathrm{~cm}$. Fire experiments evaluated the structure stability, impermeability to hot gases and smoke and thermal insulation of each sample. Results showed that the structural system with $1.2 \mathrm{~kg} / \mathrm{m}^{3}$ polypropylene fiber mortar coating obtained the best thermal insulation effect with the longest fire resistance time of 176 $\min$.
\end{abstract}

Keywords: Fire safety, polypropylene fiber, lime, fire resistance.

\section{Introduction}

Ceramic block masonry is an alternative building technique for vertical structural systems (Anicer, 2015) attractive in some countries due to its low cost and satisfactory mechanical performance (Camacho, 2006; Agopyan et al., 2009). However, while mechanical performance guaranteed the physical integrity of the construction, resistance to high temperatures must also be determined (ABNT NBR 15575:2013; EN 1996:2012). When exposed to high temperatures, 
internal structural changes caused an increase in internal tensions and reduced the mechanical properties of ceramic blocks (Costa \& Silva, 2006). To some extent, ceramic materials were able to mitigate these effects due to their low thermal expansion and thermal conductivity (around $0.25 \mathrm{~W} / \mathrm{m} \cdot \mathrm{K})($ Ayala, 2010). Ceramic blocks fired at temperatures of up to $1,000^{\circ} \mathrm{C}$ caused the clay to undergo internal physiochemical reactions that intensified re-crystallization of new ceramic phases and induced glazing. However, temperatures higher than that led to mechanical resistance loss in the clay (Pinheiro \& Holanda, 2010).

Mortars used between blocks or as coating, while contributing to the structural performance of masonry, affected the temperature distribution of ceramic blocks since they acted as thermal barriers reducing temperature variations (Ingham, 2009). Coating mortars were also passive to damage from high temperature which caused changes in its structure, mass loss and flaking that exposed the structural blocks directly to heat. Studies were conducted to increase the adhesiveness of mortar coatings to structural blocks and reduce cracking, thus preserving the integrity of the coating under heating (Silva \& Barros, 2007; Karahan, 2011; Zhang et al., 2016.). To this end, materials with insulating properties were added to mortar coatings such as lime (Pachta, Triantafyllaki, Stefanidou, 2018) and polypropylene fibers (Pacheco et al., 2016; Al-Hadhrami \& Ahmad, 2008). Lime increased the resistance to traction (Oliveira, 2001) which affected how the coating responded to thermo-mechanical deformations like thermal bowing (Russo \& Sciarretta, 2012). Polypropylene fibers incorporated in mortar decreased the appearance of fissures, spalling and deformation rate and increased resistance (Zhang et al., 2016). Additionally, melting fibers under heating created empty spaces which acted as insulation and reduced heat transfer (Ezziane et al., 2015).

According to Nguyen \& Meftah (2012) and Andrade \& Tutikian (2011), horizontal displacements of structural masonry were of lower amplitude than veneer masonry. This was a result of constraints placed between the base and ceiling of the structure by loading. This is shown in Figure 1 as the unloaded masonry wall deforms more under heating when compared to a loaded wall. Deformations in structural masonry caused by thermal loads were transmitted to the plaster lining causing fissures, detachment and flaking.

Figure 1. Deformations of masonry subjected to fire: without load (left) and under load (right). Source: Nguyen \& Meftah (2012).

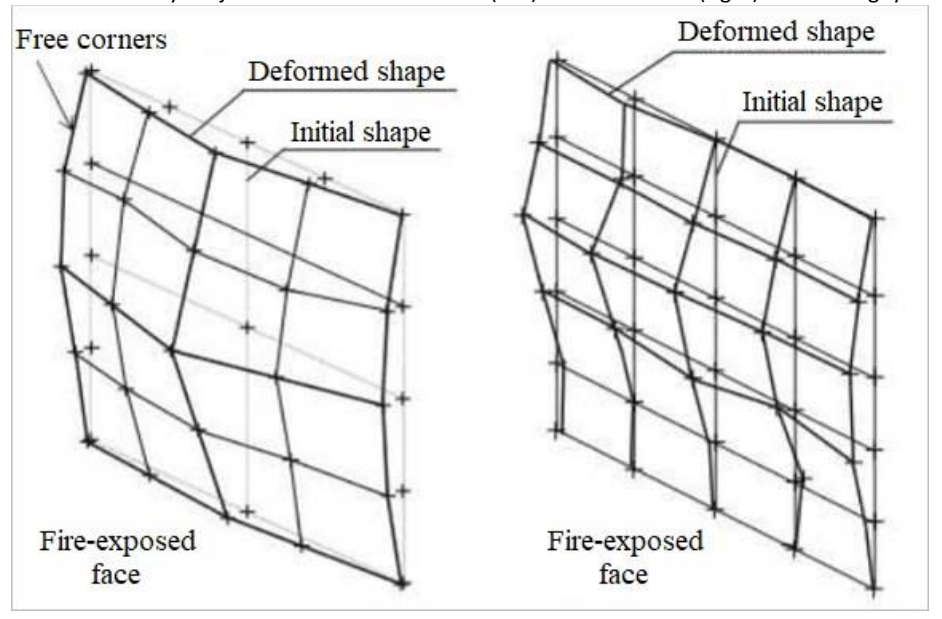

Regarding solid materials, Rigão (2012) and Gil et al. (2017) cited that heat transfer was not immediate due to their capacity to absorb and dissipate heat. However, in the case of ceramic blocks containing internal empty partitions, heat transfer became a combined radiation and conduction mechanism which retarded heat transfer and created a thermal insulation effect as seen in Figure 2.

Figure 2. Heat transfer mechanisms in hollow blocks. Source: adapted by Souza (2017) from Nguyen \& Meftah (2012).

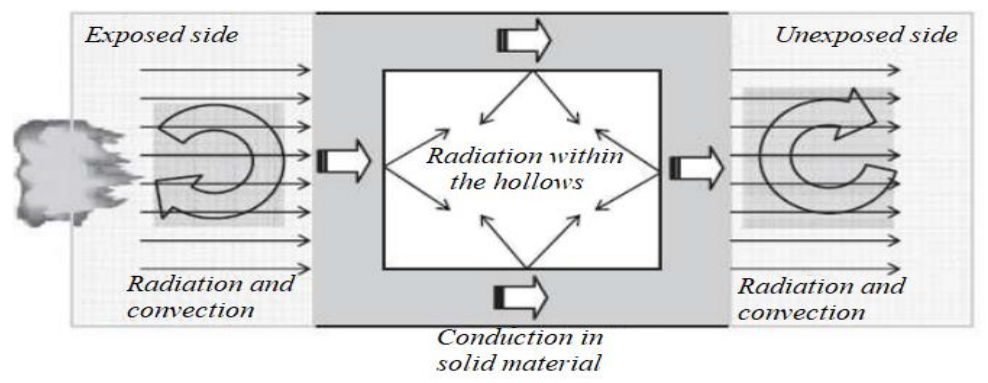


Mortar behavior under heating can be better understood by the initial loss of mass from drying, followed by ettringite decomposition and C-S-H (calcium silicate hydrate) dehydration. From then, effects would then continue to mass loss of $\mathrm{C}-\mathrm{S}-\mathrm{H}$, portlandite decomposition and finally to total degradation of portlandite and chemical reactions. Karahan (2011) tested mortar made from cement and sand heated to elevated temperatures and kept afterwards for $24 \mathrm{~h}$ under normal conditions. Results determined that compression resistance was measured as $92 \%$ of the reference value at 400 ${ }^{\circ} \mathrm{C}, 28 \%$ of the reference value at $800{ }^{\circ} \mathrm{C}$ and $6 \%$ of the reference value at $1,000{ }^{\circ} \mathrm{C}$. Rigão (2012) noted that at temperatures around $900^{\circ} \mathrm{C}$, mortars tended to lose all resistance. In the case of mortar between blocks heated to this temperature, system rupture would occur due to mortar squashing even if the blocks remained unbroken. Ingham (2009) and Pacheco et al. (2018) agreed that compression resistance decreased in structural masonry due to mortar deterioration under heating.

Polypropylene fibers were added to cement mixtures to increase toughness and to make the material more resistant to deformations and fissuring (Silva and Barros, 2007; Tiscoski \&F Antunes, 2007; Dawood \& Ramli, 2011; Zhang et al., 2016). Additional effects included rheological changes that affected adhesiveness of coatings (Monte; Barros; Figueiredo, 2012) and resistance to traction and compression (Bendjillali et al., 2011). Amaral et al. (2012) noted that artificial polymer fibers added to concrete and cement mortars had advantageous effects at high temperatures. The fibers increased water retention and, by extension, porosity and thermal insulation (Monte; Barros; Figueiredo, 2012); Centofante \& Dagostini, 2014). Polypropylene fiber deterioration, with melting starting at around $150{ }^{\circ} \mathrm{C}$ and ending around $400{ }^{\circ} \mathrm{C}$, created pores that acted as pathways for water evaporation. Centofante \& Dagostini (2014) measured an increase of $18 \%$ in resistance to traction and flexing in mortar with added fiber. However, Tiscoski \& Antunes (2007) also reported added resistance to adhesiveness of mortars with added fiber when compared to those without.

Magalhães \& Veiga (2005) studied the effect of mortars with added lime. Results showed increase adhesiveness when compared to a cement-only based mortar and increased water retention due to the fineness of lime particles. Arandigoyen \& Alvarez (2007) concluded that mortars rich in limestone had a plastic behavior zone and were able to better absorb substantial structural displacements. On the other hand, improvements in the Young modulus of mortar with polypropylene fibers for temperatures up to $500^{\circ} \mathrm{C}$ were identified by Ezziane et al. (2015).

Ceramic materials in building blocks, having undergone firing, did not suffer micro structural changes when heated to temperatures lower than the same $950{ }^{\circ} \mathrm{C}$ reached during production (Rigão, 2012). However, mortar coatings which were used to protect ceramic blocks underwent chemical transformations at lower temperatures and had its mechanical performance degraded (Morsy et al., 2012; Yazici; Sezer; Sengul, 2012). Consequently, this study was conducted in order to ascertain improvements in fire resistance of structural walls with mortar coatings. The experiments were conducted in real scale on three walls with coatings containing lime and two types of polypropylene fibers. All walls were constructed with the same ceramic block base and subjected to a standard fire growth curve defined in ISO 834 (ISO, 1999).

\section{Materials and methods}

\section{Vertical Structural Systems}

The vertical structural systems used in this study consisted of wall samples $3.00 \mathrm{~m}$ in width and $2.80 \mathrm{~m}$ in height. The walls were constructed from ceramic blocks (Table 1) $14 \mathrm{~cm} \times 19 \mathrm{~cm} \times 29 \mathrm{~cm}$ (depth x height x width) with characteristic compression resistance of $7 \mathrm{MPa}$ and industrialized mortar.

Table 1. Ceramic blocks characteristics. Source: elaborated by the authors.

\begin{tabular}{ccc}
\hline & Dimensions $(\mathrm{mm})$ & $140 \times 193 \times 293$ \\
Geometric characteristics & Flatness $(\mathrm{mm})$ & 0.69 \\
& Static lean $(\mathrm{mm})$ & 0.38 \\
& Wetted area $\left(\mathrm{mm}^{2}\right)$ & 172.21 \\
& Surface area $\left(\mathrm{mm}^{2}\right)$ & 113.47 \\
\hline \multirow{2}{*}{ Water absorption } & Initial absorption rate & 46.43 \\
& $\left(\mathrm{~g} / 193.55 \mathrm{~cm}^{2}\right) / \mathrm{min}$ & 0.19 \\
\hline Mechanical resistance & Total absorption $(\%)$ & 7.03 \\
\hline
\end{tabular}


The mortar coatings used are described in Table 2. The effective minimal area exposed to fire was of $8.4 \mathrm{~m}^{2}$ and a constant load of $10 \mathrm{tf} / \mathrm{m}$ was applied throughout heating.

Table 2. Composition of mortar coatings. Source: elaborated by the authors.

\begin{tabular}{ll}
\hline Type & \multicolumn{1}{c}{ Composition } \\
\hline Coating 1 - C1 & ratio $1: 5$ (cement: sand by volume) \\
& with $60 \mathrm{~kg} / \mathrm{m}^{3}$ lime addition \\
& ratio $1: 5$ (cement: sand by volume) \\
Coating 2 - C2 & with $0.6 \mathrm{~kg} / \mathrm{m}^{3}$ polypropylene fiber \\
& addition \\
Coating $3-\mathrm{C} 3$ & ratio $1: 5$ (cement: sand by volume) \\
& with $1.2 \mathrm{~kg} / \mathrm{m}^{3}$ polypropylene fiber \\
\hline
\end{tabular}

Each wall was constructed in a movable gate for ease of coupling to the vertical oven as seen in Figure 4 and cured for 90 days prior to testing.

Figure 4. Wall construction and coupling to vertical oven. Source: elaborated by the authors.
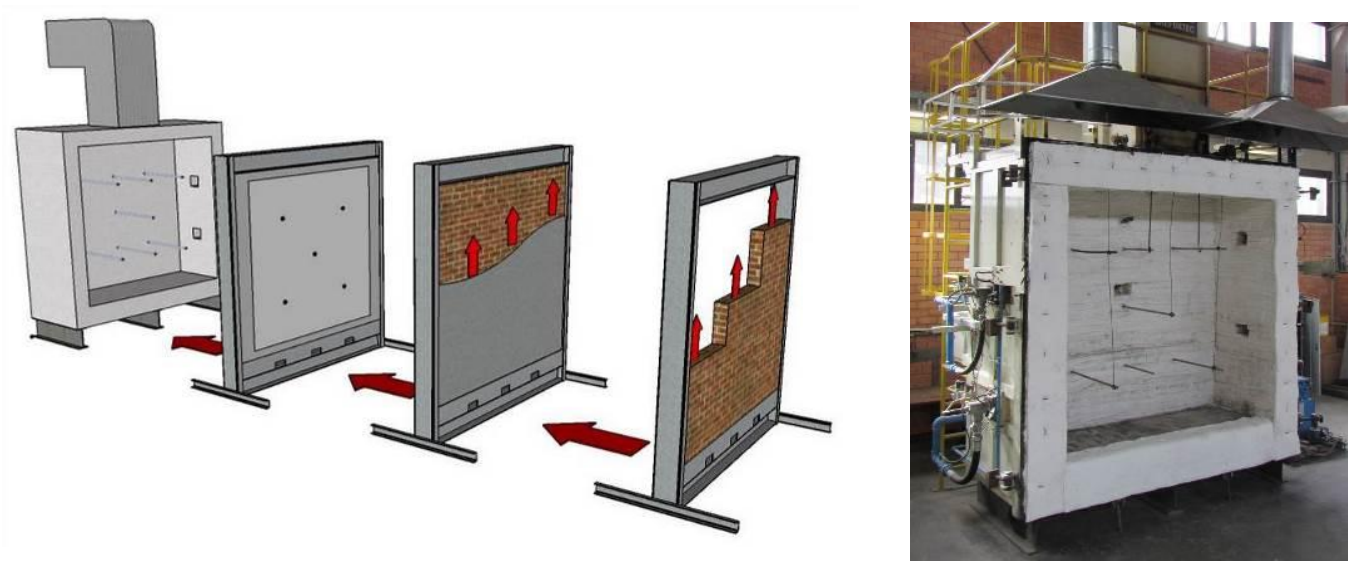

\section{Types of Mortar Coating}

The walls were constructed with two types of mortars. Mortar applied between blocks $(A)$ was produced with a mixing ratio of 1:0.4:7.4 (cement, lime and sand in volume) while mortar coatings (C1, C2 and C3) were composed with a mixing ratio of 1:5 (cement and sand in volume) and 3 types of additives as shown in Table 2 . Characteristics of fresh, dry and mortar classification are shown in Tables 3, 4 and 5, respectively. The thickness of the coating was of 1.5 on the inside exposed to fire and $2.5 \mathrm{~cm}$ in the outside. The polypropylene fibers used as additives were of monofilament type, 12 $\mathrm{mm}$ in length and with high alkaline resistance.

Table 3. Characteristics of fresh mortars. Source: elaborated by the authors.

\begin{tabular}{llllll}
\hline \multirow{2}{*}{$\begin{array}{l}\text { Characteristic } \\
\text { Spreading consistency }\end{array}$} & Methodology & \multicolumn{4}{c}{ Results } \\
\cline { 3 - 6 } $\begin{array}{l}\text { concrete }(\mathrm{mm}) \\
\text { Air content }(\%)\end{array}$ & NBR 13276 (ABNT, 2016) & 254 & 212 & 227 & 237 \\
Density $\left(\mathrm{kg} / \mathrm{m}^{3}\right)$ & NBR NM 47 (ABNT, 2002) & 4.4 & 3.8 & 3.4 & 3.8 \\
\hline
\end{tabular}


Table 4. Characteristics of dry mortars. Source: elaborated by the authors.

\begin{tabular}{|c|c|c|c|c|c|}
\hline \multirow{2}{*}{ Characteristic } & \multirow{2}{*}{ Methodology } & \multicolumn{4}{|c|}{ Results } \\
\hline & & A & C1 & $\mathrm{C} 2$ & $\mathrm{C} 3$ \\
\hline Compression resistance (MPa) & NBR 13279 (ABNT, 2005) & 2.2 & 4.56 & 1.97 & 1.16 \\
\hline $\begin{array}{l}\text { Resistance to traction and flexing } \\
\text { (MPa) }\end{array}$ & NBR 13279 (ABNT, 2005) & 1.52 & 2.06 & 0.75 & 0.32 \\
\hline Density $\left(\mathrm{kg} / \mathrm{m}^{3}\right)$ & NBR 13280 (ABNT, 2005) & $1,501.55$ & $1,836.36$ & $1,793.24$ & $1,754.24$ \\
\hline Capillary absorption, $10 \mathrm{~min}\left(\mathrm{~g} / \mathrm{cm}^{2}\right)$ & NBR 15259 (ABNT, 2005) & 1.13 & 0.19 & 0.49 & 0.42 \\
\hline Capillary absorption, $90 \mathrm{~min}\left(\mathrm{~g} / \mathrm{cm}^{2}\right)$ & NBR 15259 (ABNT, 2005) & 1.28 & 0.8 & 1.1 & 0.93 \\
\hline $\begin{array}{l}\text { Coefficient of capillary absorption } \\
\left(\mathrm{g} / \mathrm{dm}^{2} \cdot \min ^{1 / 2}\right)\end{array}$ & NBR 15259 (ABNT, 2005) & 2.44 & 9.77 & 9.75 & 8.2 \\
\hline Void space (\%) & NBR 15259 (ABNT, 2005) & 41.48 & 22.3 & 34.56 & 35.73 \\
\hline Total absorption (\%) & NBR 9778 (ABNT, 2009) & 32.29 & 12.62 & 21.22 & 21.86 \\
\hline
\end{tabular}

Table 5. Classification of mortars. Source: elaborated by the authors.

\begin{tabular}{|c|c|c|c|c|c|c|c|c|}
\hline \multirow[t]{2}{*}{ Characteristics } & \multicolumn{2}{|c|}{$A$} & \multicolumn{2}{|c|}{$\mathrm{C} 1$} & \multicolumn{2}{|c|}{$\mathrm{C} 2$} & \multicolumn{2}{|c|}{$\mathrm{C} 3$} \\
\hline & Results & Class & Results & Class & Results & Class & Results & Class \\
\hline Compression (MPa) & 2.2 & $\mathrm{P} 2$ & 4.56 & P4 & 1.97 & $\mathrm{P} 2$ & 1.16 & $\mathrm{P} 1$ \\
\hline $\begin{array}{l}\text { Traction and flexing } \\
\text { (MPa) }\end{array}$ & 1.52 & $\mathrm{C} 2$ & 2.06 & C3 & 0.75 & $\mathrm{C} 1$ & 0.32 & $\mathrm{C} 1$ \\
\hline Density $\left(\mathrm{kg} / \mathrm{m}^{3}\right)$ & $1,501.6$ & M4 & $1,836.4$ & M5 & $1,793.2$ & M4 & $1,754.3$ & M4 \\
\hline $\begin{array}{l}\text { Coefficient of capillary } \\
\text { absorption } \\
\left(\mathrm{g} / \mathrm{dm}^{2} \cdot \min ^{1 / 2}\right)\end{array}$ & 2.44 & $\mathrm{C} 2$ & 9.77 & $\mathrm{C} 5$ & 9.75 & $\mathrm{C} 5$ & 8.2 & $\mathrm{C} 5$ \\
\hline Bulk density $\left(\mathrm{kg} / \mathrm{m}^{3}\right)$ & $1,696.07$ & D4 & $1,893.19$ & D5 & $1,874.06$ & D5 & $1,798.83$ & D4 \\
\hline
\end{tabular}

\section{Instrumentation}

A Leica TS15 total station was used with a mesh of 49 virtual points to monitor structural stability and deformations on the walls during experiments. A thermographic camera FLIR A320 was used to monitor surface temperatures along with thermocouples installed in the inside of the oven and on the surface of the walls. Internal temperatures were measured with 9 thermocouples installed at different depths and locations within the center of the wall, as seen in Figure 5 . In total, 19 thermocouples were used to measure temperatures.

Figure 5. Thermocouple locations within the wall. Source: elaborated by the authors.

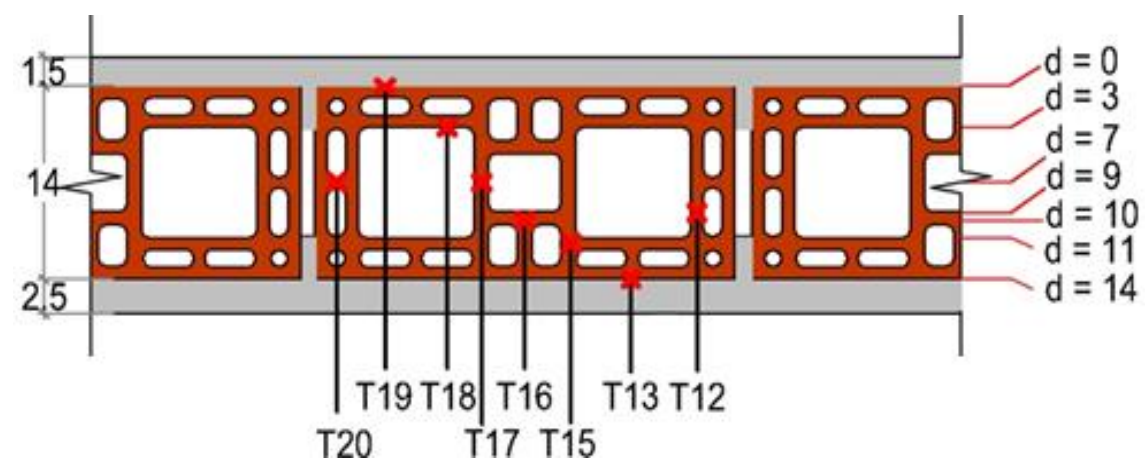




\section{Fire Resistance Experients}

The walls were subjected to fire exposure conditions and evaluated with regards to structural stability, impermeability to gases and smoke and heat insulation following the criteria of ISO 834-1 (ISO, 1999) and NBR 5628 (ABNT, 2001).

\section{Results and discussion}

The mortar characteristics presented in Table 4 were obtained following norm NBR 13281 (ABNT, 2005). Mortar used between blocks (A) had a measured compression resistance of $2.2 \mathrm{MPa}$ which contributed to a structural stability loss to the systems. As for the mortar coatings, polypropylene fiber addition (C2 and C3) presented low resistance to traction and flexing which also resulted in low adhesiveness to the wall during fire resistance experiments.

\section{Fire Resistance}

Fire resistance time for samples C1, C2 and C3 were measured to be $130 \mathrm{~min}, 162 \mathrm{~min}$ and $176 \mathrm{~min}$, respectively. These times corresponded to the collapse of the structural systems as shown in Figure 6.

(a)

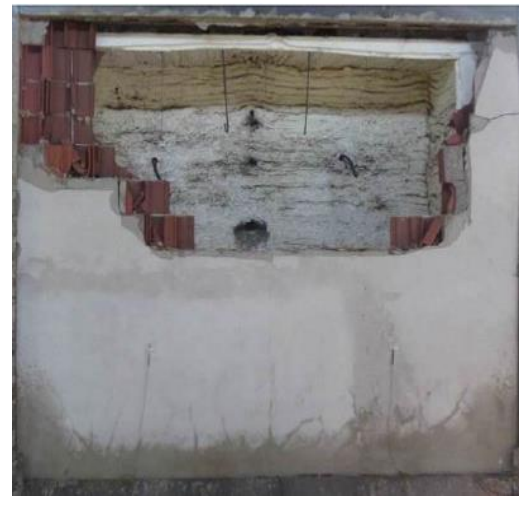

Lime lining at 130 mins

Figure 6. Structural collapse of mortar linings under heating. Source: elaborated by the authors.

(b)

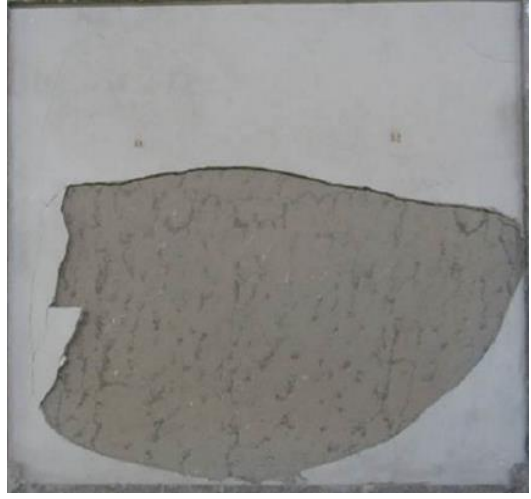

$0.6 \mathrm{~kg} / \mathrm{m}^{3}$ polypropylene fiber lining at 162 mins (c)

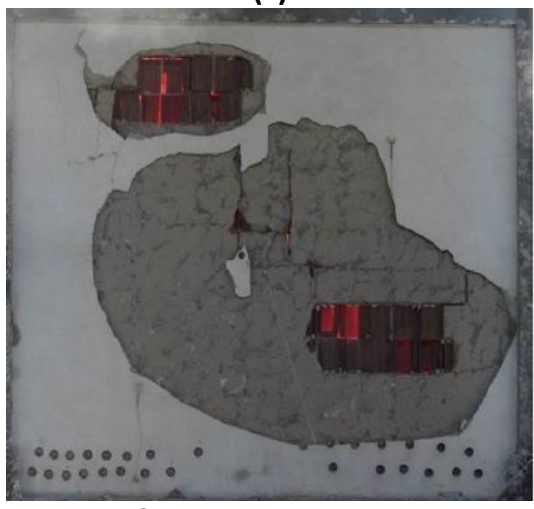

$1.2 \mathrm{~kg} / \mathrm{m}^{3}$ polypropylene fiber lining at 176 mins

Figure 7 shows thermographic images of the sides of each sample not exposed to fire moments prior to structural collapse.

Figure 7. Thermographic images of the outside face of the systems not exposed to fire moments before structural collapse. Source: elaborated by

(a)

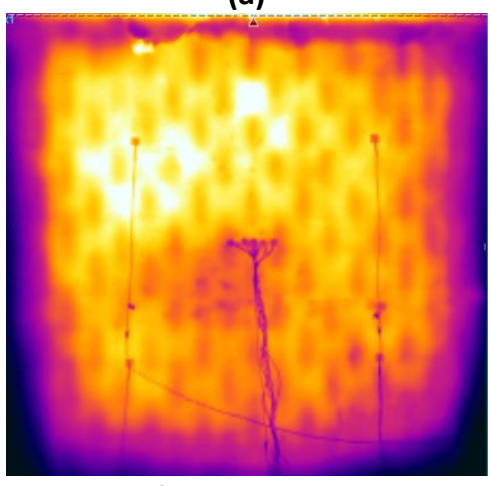

Lime lining at 130 mins (b)

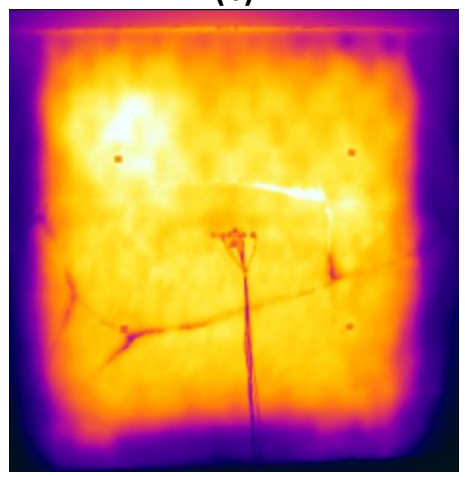

$0.6 \mathrm{~kg} / \mathrm{m}^{3}$ polypropylene fiber lining at 162 mins (c)

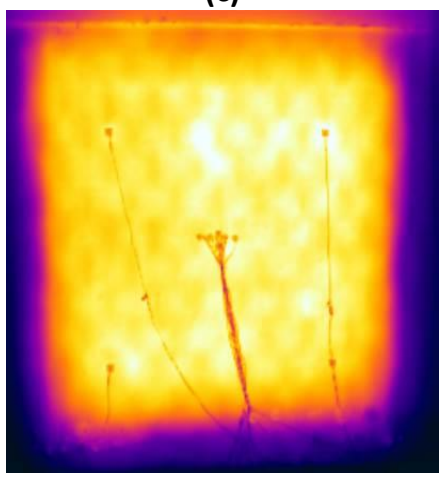

$1.2 \mathrm{~kg} / \mathrm{m}^{3}$ polypropylene fiber lining at $\mathbf{1 7 6}$ mins $220.7^{\circ} \mathrm{C}$

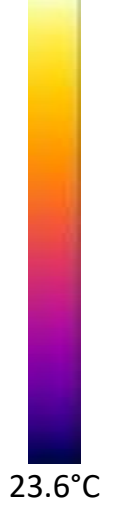

$23.6^{\circ} \mathrm{C}$

Figure 8 shows the temperature profiles at selected depth positions (d) along internal partitions of the wall for each sample. A decrease in the temperature gradient was observed with increasing depth with substantial drops from positions $\mathrm{d}=0 \mathrm{~cm}$ to $\mathrm{d}=3 \mathrm{~cm}$ and positions $\mathrm{d}=10 \mathrm{~cm}$ to $\mathrm{d}=14 \mathrm{~cm}$. This was a result of solid material absorbing and 
dissipating heat, thus causing a time delay in heat transfer. The least reduction in thermal gradient and consequently poorer thermal isolation performance was observed between positions $\mathrm{d}=3 \mathrm{~cm}$ and $\mathrm{d}=10 \mathrm{~cm}$ due to the presence of a large empty cell which prompted a mixed convection-radiation heat transfer mode. Based on this result, it could be concluded that the inside and outside wall faces were more thermally insulating as the other layers due to their balance of solid material and empty space. This suggested that blocks with a more homogenous distribution of empty spaces should offer better fire resistance performance.

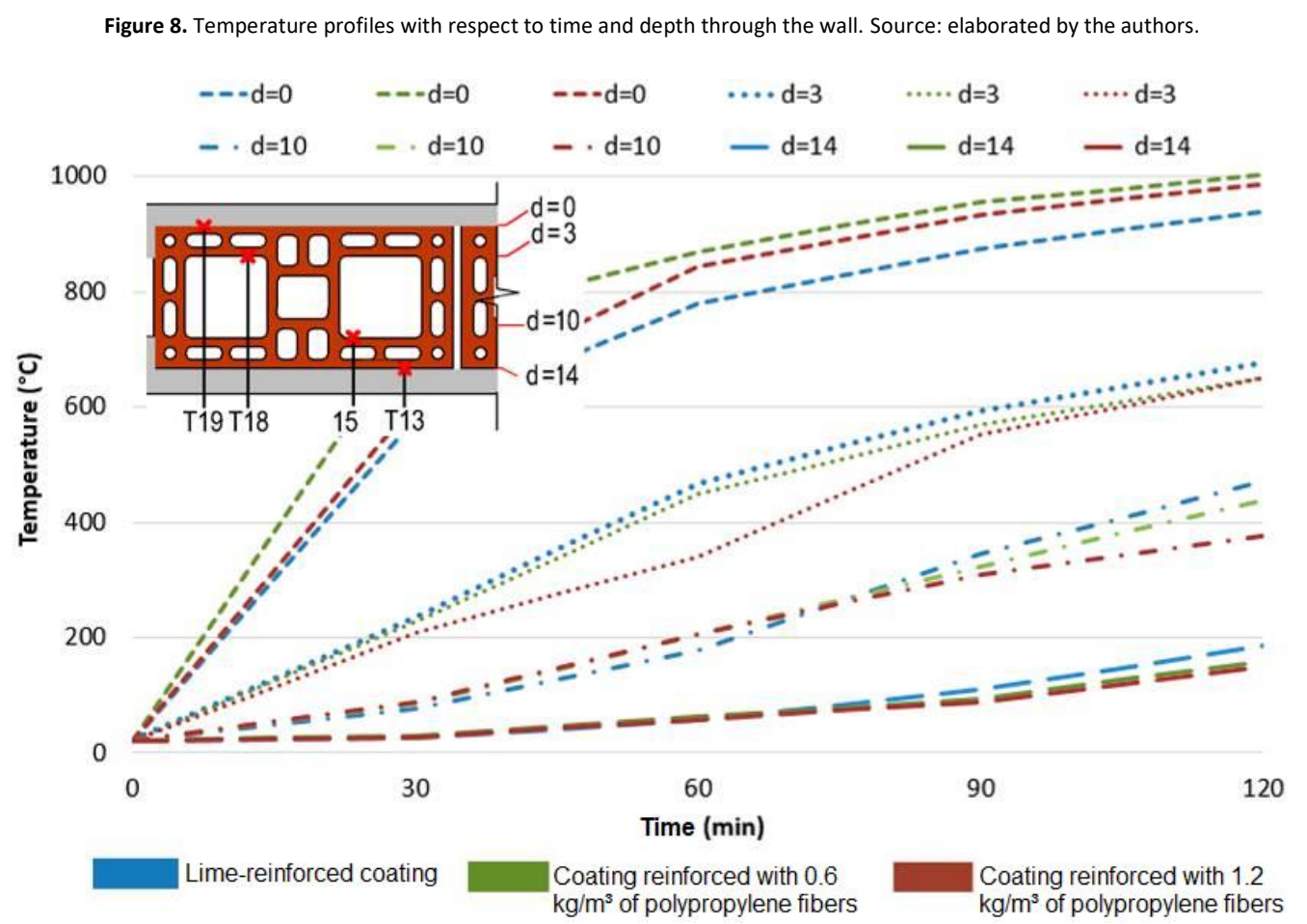

Position $\mathrm{d}=0 \mathrm{~cm}$ presented a temperature profile similar to the standard experimental curve probably due to flaking of the internal face of the wall. At this location, lime mortar coating performed better than the polypropylene fiber samples. Internal wall flaking could be related to excessive vertical deformation observed once the wall became loaded as seen in Figure 9.

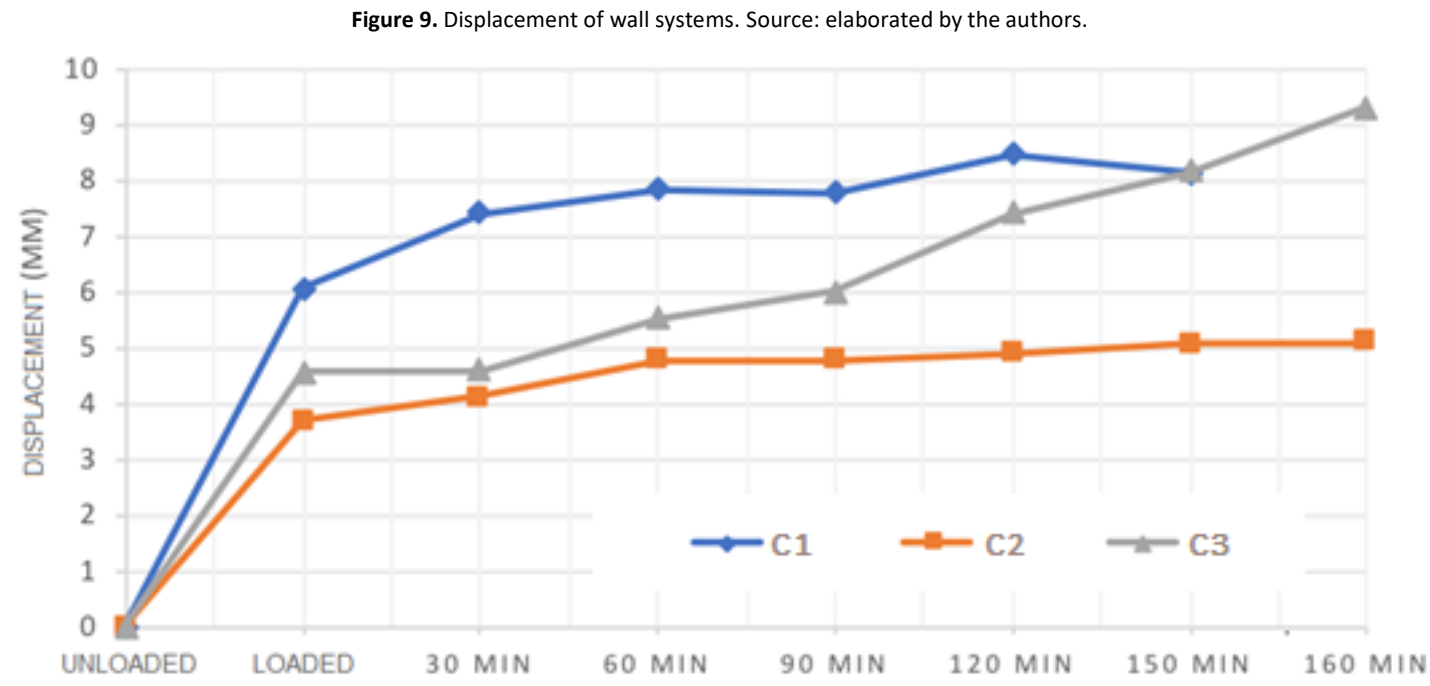

The low compression resistance of the mortar applied between blocks resulted in squashing as seen in Figure 10. This resulted in tensions being redirected towards the coating and coupled with the tendency of the wall to curve towards the fire, promoted flaking. 
Figure 10. Results at the end of the tests. Source: elaborated by the authors.
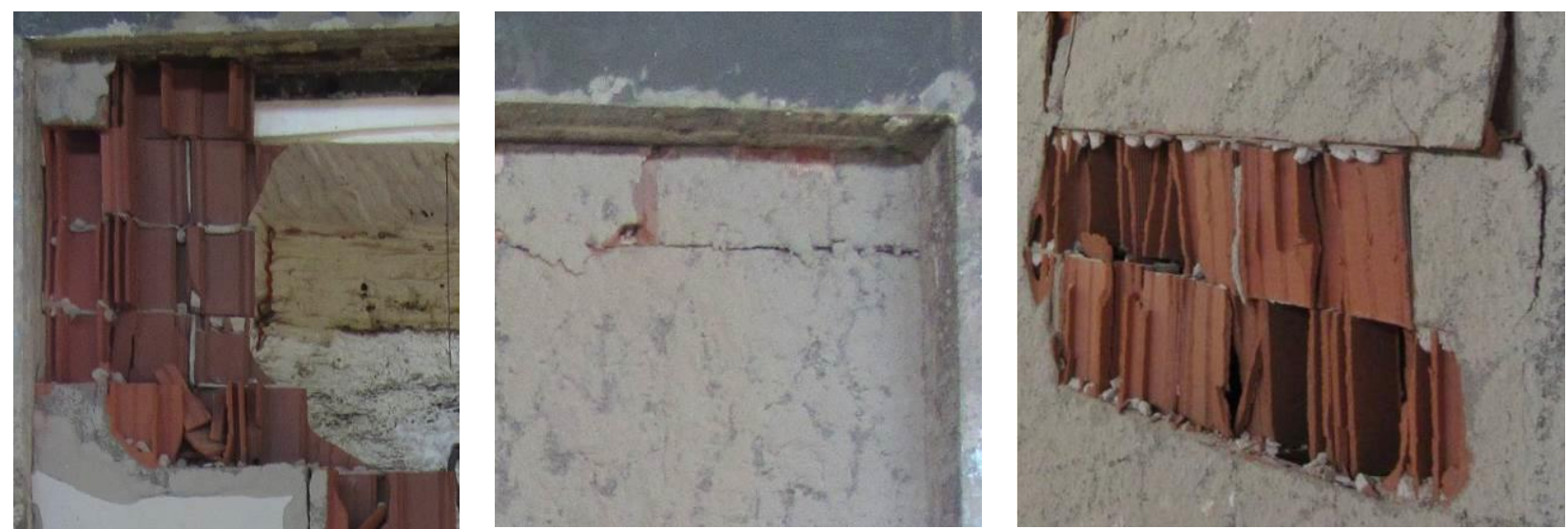

Thermal insulation performance was evaluated from the average and local outside wall temperatures of the 3 samples at 120 min shown in Table 6. There was a significant difference in temperature with sample $\mathrm{C} 1$ being much higher than samples C2 and C3. A study by Souza (2017) with similar masonry walls obtained a fire resistance time of 102 min on the bare wall facing the fire but also determined that mortar linings with added fiber performed better as thermal insulation.

Figure 11 shows the time-evolution of temperatures at position $\mathrm{d}=14 \mathrm{~cm}$ on the outside of the walls for the reference and 3 samples. The effect of the external mortar coating became more visible after 90 min as the temperature curves diverged. Samples with added polypropylene fiber performed better as thermal insulation as the fibers started melting at around $150^{\circ} \mathrm{C}$.

Figure 11. Thermal performance of reference and mortar coatings on the outside of the wall. Source: elaborated by the authors.

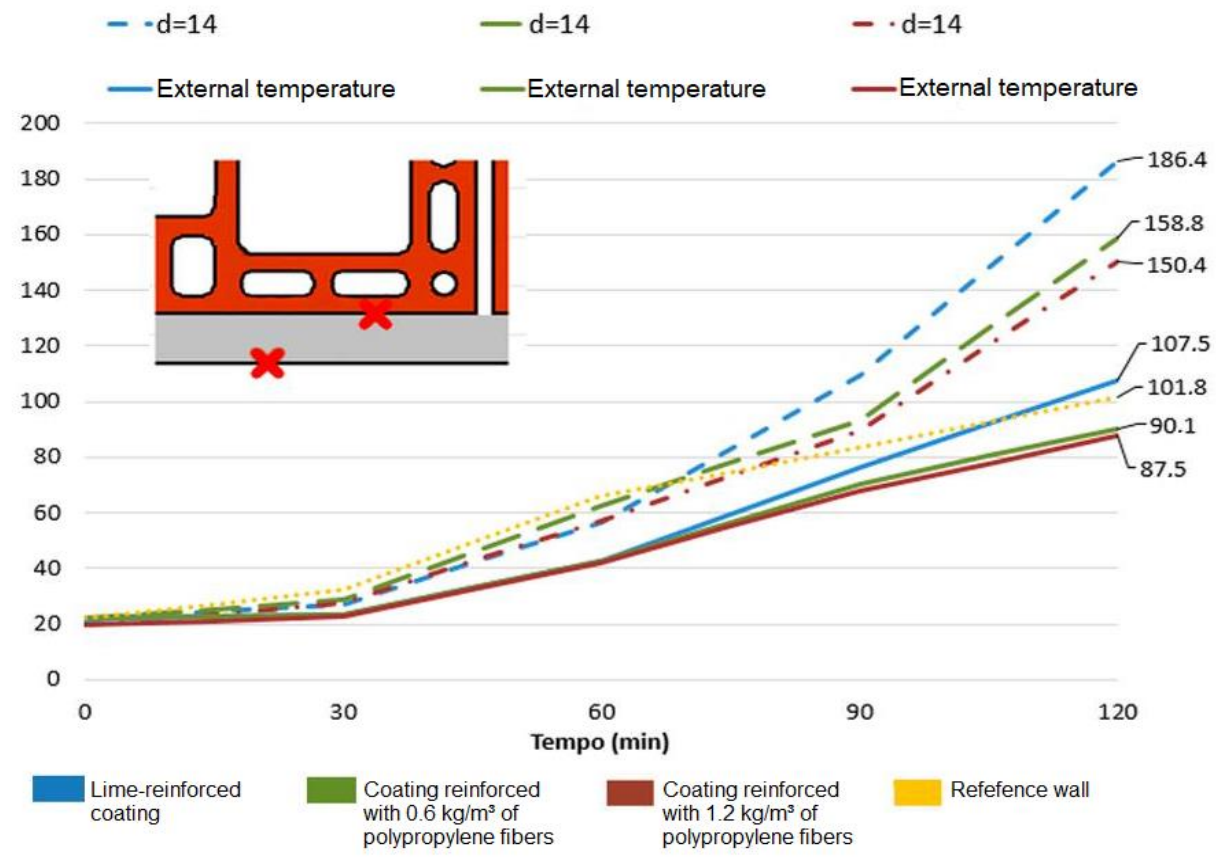

This behavior could also be explained by the higher water content in mortars with fiber, which increased void spaces and total absorption reported in Table 4. As noted by Metha \& Monteiro (2014), cement mixtures with high water content exposed to high temperatures had slower temperature rises until all water content evaporated. Overall, sample C3 was more efficient when compared to samples C2 and C1. 
The structural system with coating C1 performed the least when compared to the other types of coatings with a fireresistance rating (FRR) of $130 \mathrm{~min}$. Nevertheless, it was able to meet the criteria of structural stability, impermeability to gases and smoke and thermal insulation. Structural systems with coatings $\mathrm{C} 2$ and $\mathrm{C} 3$ obtained relatively superior performances in accordance to the density of polypropylene fibers with FRRs of $162 \mathrm{~min}$ and $176 \mathrm{~min}$, respectively.

It was concluded that lining mortars with added fibers were able to achieve better fire resistance in accordance to the amount added. This was a result of increased water retention which slowed down the temperature rise across the wall. In addition, pores were formed within the mortars which forced a mixed heat transfer mode of conduction and radiation and created a further heat insulation effect.

References

Andrade, J. \& Tutikian, B. (2011). Resistência mecânica do concreto. In: ISAIA, Geraldo Cechella. Concreto: Ciência e Tecnologia. São Paulo: IBRACON, Brazil. Ch. 17. p. 615-651.

Associação Nacional Da Indústria Cerâmica. (2015). ANICER. Retrieved from: <http://www.anicer.com.br>. Date viewed: 24 nov. 2015.

Associação Brasileiras De Normas Técnicas. (2001). NBR 5628: Componentes construtivos estruturais - Determinação da resistência ao fogo. Rio de Janeiro.

Associação Brasileiras De Normas Técnicas. (2001). NBR 14432: Exigências de resistência ao fogo de elementos construtivos de edificações Procedimento. Rio de Janeiro.

Associação Brasileiras De Normas Técnicas. (2013). NBR 15575: Edificações habitacionais - Desempenho. Parte 4: Requisitos para os sistemas de vedações verticais internas e externas - SVVIE. Rio de Janeiro.

Associação Brasileiras De Normas Técnicas. (2005). NBR 15259: Argamassa para assentamento e revestimento de paredes e tetos - Determinação da absorção de água por capilaridade e do coeficiente de capilaridade. Rio de Janeiro.

Associação Brasileiras De Normas Técnicas. (2002). NBR NM 47: Concreto - determinação do teor de ar em concretos frescos - Método pressométrico. Rio de Janeiro.

Associação Brasileiras De Normas Técnicas. (2016). NBR 13276: Argamassa para assentamento e revestimento de paredes e tetos - Determinação do índice de consistência. Rio de Janeiro.

Associação Brasileiras De Normas Técnicas. (2005). NBR 13278: Argamassa para assentamento de paredes e revestimento de paredes e tetos Determinação da densidade de massa e do teor de ar incorporado. Rio de Janeiro.

Associação Brasileiras De Normas Técnicas. (2005). NBR 13279: Argamassa para assentamento de paredes e revestimento de paredes e tetos Determinação da resistência à tração na flexão e à compressão. Rio de Janeiro.

Associação Brasileiras De Normas Técnicas. (2005). NBR 13280: Argamassa para assentamento e revestimento de paredes e tetos - Determinação da densidade de massa aparente no estado endurecido. Rio de Janeiro.

Associação Brasileiras De Normas Técnicas. (2005). NBR 13281: Argamassa para assentamento de paredes e revestimento de paredes e tetos Requisitos. Rio de Janeiro.

Associação Brasileiras De Normas Técnicas. (2005). NBR 9778: Argamassa e concreto endurecidos - Determinação da absorção de água, índices de vazios e massa específica. Rio de Janeiro.

Agopyan, V., Souza, U. E. L., Paliari, J. C., \& Andrade, A. C. (2009). Alternativas para redução do desperdício de materiais nos canteiros de obra.

Al-Hadhrami, L. M. \& Ahmad, A. (2009). Assessment of thermal performance of different types of masonry bricks used in Saudi Arabia. Applied Thermal Engineering, 29 .

Amaral, E. C., Botelho, R. A., Lameiras, F. S., Reis, S. C. \& Tolentino, E. (2012). O efeito do tratamento térmico a $300{ }^{\circ} \mathrm{C}$ na conectividade da estrutura de poros de argamassas de cimento Portland reforçadas por fibras de polipropileno. Órgão oficial da associação brasileira de cerâmica - ano Iviii - v. 58, 346 - abr/mai/jun 2012.

Arandigoyen, M. \& Alvarez, J. I. (2007). Pore structure and mechanical properties of cement-lime mortars. Cement and Concrete Research, 37(5), 767775.

Ayala, F. R. R. (2010). Mechanical properties and structural behaviour of masonry at elevated temperatures, Ph.D. Thesis, University of Manchester.

Bendjillali, K,; Goual, M. S., Chemrouk, M. \& Damene, Z. (2011). Study of the reinforcement of limestone mortars by polypropylene fibers waste. Physics Procedia 21, 42-46.

Camacho, J. S. (2006). Projeto de edifícios de alvenaria estrutural. Núcleo de Ensino e Pesquisa da Alvenaria Estrutural - NEPAE, Ilha Solteira, São Paulo.

Centofante, G. \& Dagostini, C. M. (2014). Análise das propriedades de argamassa de revestimento com adição de fibras de polipropileno. Joaçaba: Unoesc \& Ciência - Acet. 
Comité Européen de Normalisation (Cen). (2005). EN 1996-1-1: Eurocode 6 - Design of masonry structures - Part 1-2: General rules - Structural fire design. Brussels.

Costa, C. N. \& Silva, V. P. (2006). Revisão histórica das curvas padronizadas de incêndio. In: Seminário Internacional NUTAU: Tecnologia de Durabilidade, 2006, São Paulo. Resumos. São Paulo: NUTAU-USP.

Dawood, E. T. \& Ramli, M. (2011). Contribution of hybrid fibers on the properties of high strength concrete having high workability. Procedia Engineering, 14, 814-820.

Ezziane, M., Kadri, T., Molez, L., Jauberthie, R. \& Belhacen, A. (2015). High temperature behaviour of polypropylene fibres reinforced mortars. Fire Safety Journal 71, 324-331.

Gil, A., Pacheco, F., Christ, R., Bolina, F., Khayat, K. H., \& Tutikian, B. (2017). Comparative study of concrete panels' fire resistance. ACl Materials Journal, 114 (5), doi: https://doi.org/10.14359/51689715

Ingham, J. (2009). Forensic Engineering of Fire- Damaged Structures. ICE, 162, 12-17.

International Organization For Standardization (ISO). (1999). ISO 834: fire resistance tests - Elements of building construction. Geneva.

Karahan, O. (2011). Residual compressive strength of fire-damaged mortar after post-fire-air-curing. Fire and Material, 35(8), 561-567.

Metha, P. K. \& Monteiro, P. J. M. (2014).Concreto: microestrutura, propriedades e materiais. 3. ed. São Paulo: IBRACON.

Monte, R., Barros, M. \& Figueiredo, A. (2012). Avaliação da influência de fibras de polipropileno na resistência de aderência de revestimentos de argamassa. São Paulo, Brazil. $12 \mathrm{p}$

Morsy, M. S., Al-Salloum, Y.A., Abbas, H. \& Alsayed, S. H. (2012). Behavior of blended cement mortars containing nano-metakaolin at elevated temperatures. Construction and Building Materials. 35, 900-905.

Nguyen, T. D. \& Meftah, F. (2012). Behavior of clay hollow-brick masonry walls during fire. Part1: experimental analysis. Fire Safety Journal, 52, 5564.

Oliveira, M. L. L. (2001). Influência da adição de fibras de polipropileno em argamassas. 2001. Master's Thesis. Pós-Graduação em Engenharia Civil. Universidade Federal de Santa Catarina, Florianópolis. Brazil.

Pacheco, F., Christ, R., Quinino, U., \& Tutikian, B. F. (2018). Effects of fiber hybridization in advanced cementitious composites durability in humid and aggressive environments. Revista Materia, 23. doi: https://doi.org/10.1590/s1517-707620180003.0505.

Pacheco, F. Christ, R. Gil, A.M. \& Tutikian, B.F (2016).SEM and 3D microtomography application to investigate the distribution of fibers in advanced cimenticious composites. Revista Ibracon de Estruturas e Materiais, 9, 824-832, doi:10.1590/s1983-41952016000600002

Pachta, V., Triantafyllaki, S. \& Stefanidou, M. (2018). Performance of lime-based mortars at elevated temperatures. Construction and Building Materials, 189, 576-584.

Pinheiro, B. C. A. \& Holanda, J. N. F. (2010). Efeito da temperatura de queima em algumas propriedades mecânicas de cerâmica vermelha. Universidade Estadual do Norte Fluminense, CCT-LAMAV, Grupo de Materiais Cerâmicos. Brazil.

Rigão, A. O. (2012). Comportamento de pequenas paredes de alvenaria estrutural frente a altas temperaturas. Master's Thesis in Civil Engineering. Universidade Federal de Santa Maria, Santa Maria, RS. Brazil.

Russo, S. \& Sciarretta, F. (2012). Experimental and theoretical investigation on masonry after high temperature exposure. Experimental Mechanics, 52(4), 341-359.

Silva, R. P. \& Barros, M. M. S. B. (2007). Revestimentos de argamassa com fibras de polipropileno. Revista Téchne. São Paulo, n. 127. Retrieved from: <http://techne.pini.com.br/engenharia-civil/127/artigo287483-1.aspx>. Date viewed: 14 may 2017.

Souza, R. P. (2017). Avaliação da influência da espessura do revestimento argamassado e do carregamento no comportamento de alvenaria frente a altas temperaturas. São Leopoldo, 2017. 133p. Dissertação (Mestrado em Engenharia Civil) - Programa de Pós-Graduação em Engenharia Civil, Unisinos, São Leopoldo.

Tiscoski, B. L., \&Antunes, E. G. P. (2007). Análise do efeito da adição de fibras de polipropileno da resistência de aderência à tração em argamassa de revestimento. Undergraduate Thesis in Civil Engineering, UNESC - Universidade do Extremo Sul Catarinense.

Yazici, S., Sezer, G. I., \& Sengul, H. (2012). The effect of high temperature on the compressive strength of mortars. Construction and Building Materials. $35,97-100$

Zhang, H., Liu, Y., Sun, H. \& Shoufeng, W. (2016). Transient dynamic behavior of polypropylene fiber reinforced mortar under compressive impact loading. Construction and Building Materials, 111, 30-42. 